
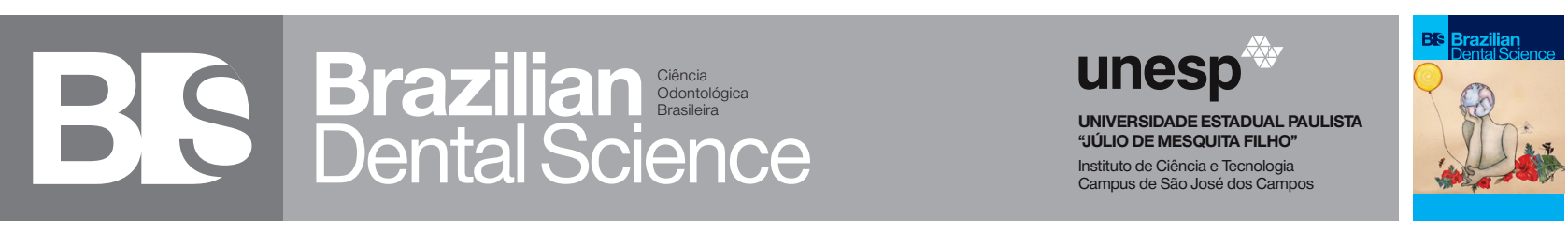

\title{
Photodynamic inactivation of planktonic cultures of Streptococcus mutans using erythrosine irradiated by LED
}

Inativação fotodinâmica de culturas planctônicas de Streptococcus mutans usando eritrosina irradiada por LED

\begin{abstract}
Maria Ângela Lacerda Rangel ESPER ${ }^{1}$, Júnia Oliveira BARBOSA², Janaína Araújo de ALVARENGA², Juliana Campos JUNQUEIRA², Alessandra Nara de Souza RASTELLI ${ }^{3}$, Sérgio Eduardo de Paiva GONÇALVES ${ }^{1}$

1 - UNESP - Univ Estadual Paulista - Institute of Science and Technology, São José dos Campos - Department of Restorative Dentistry, - São Paulo State University - UNESP - São José dos Campos, São Paulo, Brazil.

2 - UNESP - Univ Estadual Paulista - Institute of Science and Technology, São José dos Campos - Department of Biosciences and Oral Diagnosis - São José dos Campos - São Paulo - Brazil.

3 - UNESP - Univ Estadual Paulista - Department of Restorative Dentistry, Araraquara, São Paulo - Brazil.
\end{abstract}

\begin{abstract}
Objective: The aim of this in vitro study was to evaluate the efficacy of photodynamic inactivation (PDI) with erythrosine (E), using a light-emitting diode (LED) on planktonic cultures of Streptococcus mutans. Material and Methods: A Streptococcus mutans strain (UA 159) was used to prepare the suspensions containing $10^{7}$ cells $/ \mathrm{mL}$, which was tested under different experimental conditions: a) LED irradiation in the presence of erythrosine as a photosensitizer $(\mathrm{E}+\mathrm{L}+)$; b) LED irradiation only $(\mathrm{P}-\mathrm{L}+)$; c) treatment with erythrosine only $(\mathrm{E}+\mathrm{L}-)$; and d) no LED irradiation or photosensitizer (P) treatment, which served as a control group (P-L-). After treatment, strains were seeded onto MSBS agar for determination of the number of colony-forming units (CFU/mL). Results: The results were submitted to analysis of variance and the Tukey test ( $\mathrm{p}<0.05$ ). No reduction in the number of $\mathrm{CFU} / \mathrm{mL}$ was observed in the treatment group with erythrosine $(\mathrm{E}+\mathrm{L}+)$ when compared to the control (P-L-). Conclusion: PDI using erythrosine did not reduce the number of CFUs per millimeter within the parameters in this study.
\end{abstract}

\section{KEYWORDS}

Erythrosine; Decay; Photodynamic inactivation; Light-emitting diode.

\section{RESUMO}

Objetivo: o objetivo deste estudo in vitro foi avaliar a eficácia da inativação fotodinâmica (PDI) com a eritrosina (E), usando diodo de emissão de luz azul (LED) em culturas planctônicas de Streptococcus mutans. Material e métodos: a cepa de Streptococcus mutans (UA 159) foi usada para o preparo das suspensões padrões contendo $10^{7}$ células $/ \mathrm{mL}$, as quais foram testadas em diferentes condições experimentais a) irradiação com LED em presença da eritrosina como fotossensibilizador $(\mathrm{E}+\mathrm{L}+)$; b) irradiação com LED apenas (F-L+); c) tratamento com eritrosina apenas (E+L-); e d) tratamento sem irradiação com LED ou fotossensibilizador (F), que serviu como grupo controle (F-L-). Após o tratamento, as cepas foram semeadas em ágar MSBS para determinação do número de unidades formadoras de colônias (UFC/mL). Resultados: os resultados foram submetidos à análise de variância e teste de Tukey ( $\mathrm{p}<0.05)$. Não foi observada redução no número de $\mathrm{UFC} / \mathrm{mL}$ no grupo de tratamento com eritrosina $(\mathrm{E}+\mathrm{L}+)$ quando comparado ao grupo controle (F-L-). Conclusão: a PDI usando etritrosina e LED não reduziu o número de UFCs por milímetro com os parâmetros utilizados neste estudo.

\section{PALAVRAS-CHAVE}

Eritrosina; Cárie; Inativação fotodinâmica; LED; Streptococcus mutans. 


\section{INTRODUCTION}

$\mathrm{D}$ ental caries is a global oral health concern caused by an imbalance in the physiological equilibrium between tooth minerals and oral microbial biofilm [1]. Dental plaque is highly complex, formed of 30 bacterial genera and over 300 taxa, with each individual dentition site consisting of a unique microbial composition [2].

The high consumption of carbohydrates can lead to the appearance of aciduric saccharolytic flora like Streptococcus mutans, Lactobacillus species, and certain non-mutans streptococci, leading to the development of dental caries $[3,4]$. Streptococcus mutans have been known as the first bacteria that colonize oral surfaces and might make up $70 \%$ of bacteria found in dentogingival biofilm [5-7]. $S$. mutans is considered a cariogenic bacteria because its high prevalence in biofilm before the appearance of dental caries, its ability to produce a great amount of acid after the metabolism of carbohydrates, and for its survival in the environments with low $\mathrm{pH}$ $[1,2,8]$. The production of acid changes the $\mathrm{pH}$ below the critical value, causing disequilibrium and demineralization of the tooth surface if no methods of prevention take place [9-11]. The usual methods to remove the oral microbial biofilm are tooth brushing, the use of dental flossing and antiseptics. However, biofilm removal depends on patient compliance and antiseptics could produce drug-resistant microbes and lead to other side effects [12].

The use of photodynamic inactivation (PDI) can be an alternative for microbial control in order to prevent dental caries and periodontal diseases [13]. PDI uses a light source (halogen lamps, laser or LED) to activate a specific photosensitizer in the presence of oxygen, producing reactive radicals that induce cell death [14]. Blue LED is commonly used in the dental office for the curing of composite resin based materials and tooth whitening, as it does not damage the oral tissues. Moreover, it is small, lightweight, low cost, has a broad spectrum output, and is easy to operate $[14,15]$. Dentists could use their usual LEDs to perform PDI in their offices, reducing their practice costs of purchasing lasers or different types of LEDs.

Erythrosine dye has been widely used in Dentistry for biofilm detection and also as a photosensitizer because it is not toxic and is approved for clinical use $[16,17]$.

Therefore, the purpose of this study was to evaluate the effect of PDI using erythrosine photosensitizer irradiated by a blue LED on the viability of Streptococcus mutans in planktonic cultures. The null hypothesis tested is that erythrosine do not decrease the numbers of $\mathrm{CFU} / \mathrm{mL}$.

\section{MATERIAL AND METHODS}

\section{Photosensitizers and light source}

Erythrosine (Sigma-Aldrich, Steinheim, Germany), at a final concentration of $10 \mu \mathrm{M}$ was used for the sensitization of $S$. mutans strain. The photosensitizer solution was prepared by dissolving each dye in saline solution $(0.85 \% \mathrm{NaCl})$. After filtration through a sterile $0.20 \mu \mathrm{m}$ Millipore membrane (GVS, Sanford, USA), the photosensitizer solution was stored in the absence of light. Figure 1 shows the absorption spectra for erythrosine and its chemical structure.

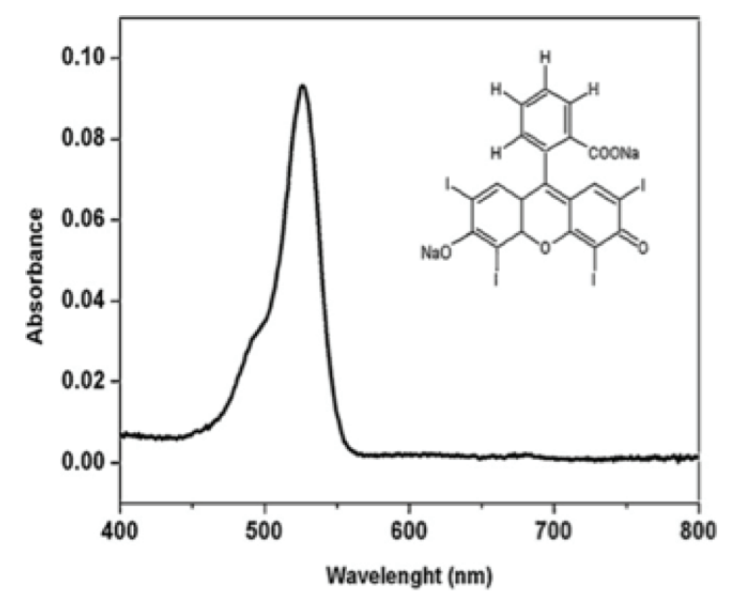

Figure 1 - Chemical structure and absorption spectrum of erythrosine [18]. 
The light source used was a wireless blue LED (Emitter C, Schuster, Santa Maria, RS, Brazil) at a wavelength of 420-480 nm, a power output of $625 \mathrm{~mW}$ and an illuminated area of $0.5 \mathrm{~cm}^{2}$. A fluence of $75 \mathrm{~J} . \mathrm{cm}^{-2}$ (energy of $37.5 \mathrm{~J}$ and irradiation time of $60 \mathrm{~s}$ as recommended by Costa et al. [19] and a fluence rate of $1250 \mathrm{~mW} . \mathrm{cm}^{-2}$ were used. Figure 2 shows the maximum emission peak of the LED used to irradiate the samples.

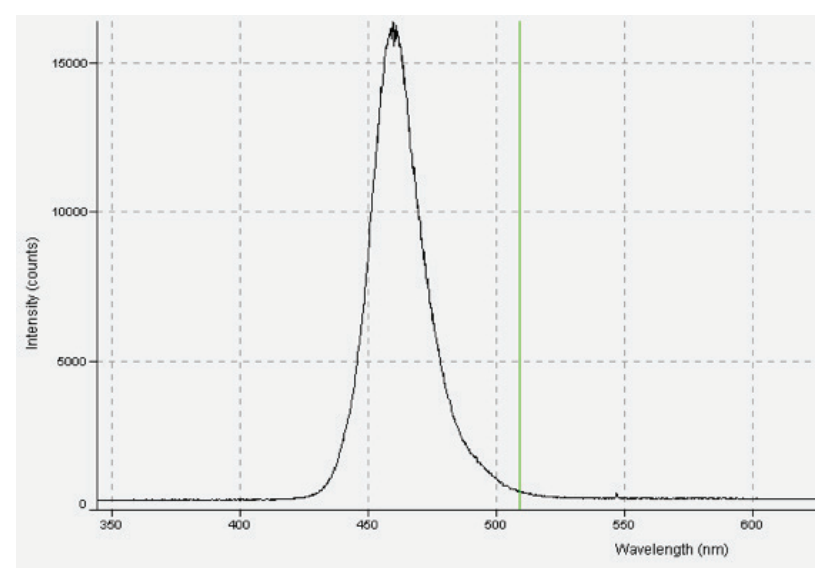

Figure 2 - Emission spectrum of the blue LED (Emitter C, Schuster, Santa Maria, RS, Brazil).

\section{Bacteria Strain}

The planktonic culture methodology was proposed by Costa et al. [19], as follows. The reference strain (UA 159) of S. mutans maintained in our laboratory stock collection was included in the study. A standard suspension containing $10^{7}$ cells $/ \mathrm{mL}$ was prepared by seeding $S$. mutans onto a brain heart infusion (BHI) and incubation for 24 $\mathrm{h}$ at $37^{\circ} \mathrm{C}\left( \pm 1^{\circ} \mathrm{C}\right)$ under microaerophilic conditions. After incubation, the bacteria were cultured in $7.5 \mathrm{~mL}$ BHI broth (Himedia) for $24 \mathrm{~h}$ at $37^{\circ} \mathrm{C}\left( \pm 1^{\circ} \mathrm{C}\right)$ under microaerophilic conditions. All incubations were carried out at $37^{\circ} \mathrm{C}\left( \pm 1^{\circ} \mathrm{C}\right)$ under $5 \% \mathrm{CO}_{2}$. The bacterial cultures were then centrifuged at $4700 \mathrm{xg}$ for $5 \mathrm{~min}$, and the supernatant was discarded and cleaned using $5 \mathrm{~mL}$ of sterile saline solution ( $0.85 \%$ sodium chloride). This procedure was repeated, and the sediment was resuspended in $5 \mathrm{~mL}$ of sterile physiological solution.

The number of cells in each suspension was measured using a spectrophotometer (B582, Micronal, São Paulo, Brazil) at a wavelength of $398 \mathrm{~nm}$ until an optical density of 0.560 was reached.

The assays were divided into four experimental conditions $(\mathrm{n}=10)$ as described in Table I.

Table I - Experimental groups

\begin{tabular}{|cc|}
\hline Evaluated groups & Description \\
\hline $\mathrm{E}+\mathrm{L}+$ & $\mathrm{LED}$ irradiation using erythrosine as photosensitizer \\
\hline $\mathrm{P}-\mathrm{L}+$ & $\mathrm{LED}$ irradiation only \\
\hline $\mathrm{E}+\mathrm{L}-$ & Treatment with erythrosine only \\
\hline $\mathrm{P}-\mathrm{L}-$ & No LED irradiation or photosensitizer treatment \\
\hline
\end{tabular}

\section{In vitro photosensitization}

According to the experimental conditions described, $0.1 \mathrm{~mL}$ of the bacterial suspension was added to each well of sterile 96-well flatbottom microtiter plates (Costar Corning, New York, USA). After that, $0.1 \mathrm{~mL}$ of the photosensitizer was added for groups $\mathrm{E}+\mathrm{L}+$ and $\mathrm{E}+\mathrm{L}-$, whereas $0.1 \mathrm{~mL}$ sterile physiological solution was added for the groups P-L+ and P-L-. The plates were shaken for $5 \mathrm{~min}$ (during the pre-irradiation time) using an orbital shaker (Solab, Piracicaba, Brazil). The well contents of groups $\mathrm{E}+\mathrm{L}+$ and $\mathrm{P}-\mathrm{L}+$ were irradiated according to the protocol described above. The distance between the light source and the bacterial cells was approximately $6 \mathrm{~mm}$. Irradiation was performed under aseptic conditions in a laminar flow hood in the dark. The plates were covered with a black screen with an orifice whose diameter corresponded to the size of the well opening in order to prevent the spreading of light to neighboring wells. After irradiation, serial dilutions were prepared, and $0.1 \mathrm{~mL}$ aliquots of each dilution were seeded in duplicate onto MSBS agar plates and incubated for 48 $\mathrm{h}$ at $37^{\circ} \mathrm{C}\left( \pm 1^{\circ} \mathrm{C}\right)$ under microaerophilic conditions. After incubation, the number of 
colony-forming units per milliliter (CFU/ $\mathrm{mL}$ ) was determined. The results were log transformed and statistical analyses were carried out with GraphPad Prism 6.0 program (GraphPad Software, Inc., San Diego, CA, USA). Analysis of Variance (one-way ANOVA) and the Tukey's test were used. A $p$ value < 0.05 was considered to indicate a statistically significant difference.

\section{RESULTS}

Figure 3 presents the mean values, standard deviations and the Tukey's test of the number of $\mathrm{CFU} / \mathrm{mL}\left(\log _{10}\right)$ obtained for the different groups. Figure 4 and Table II present the median values (crossbar), interquartile range (IQR box), minimum and maximum values of $\mathrm{CFU} / \mathrm{mL}\left(\log _{10}\right)$ obtained for the different groups. PDI with erythrosine did not induce a reduction in the numbers of $\mathrm{CFU} / \mathrm{mL}$ when compared to the control group (P-L-) (p $=0.3644)$.

$E+$ blue LED

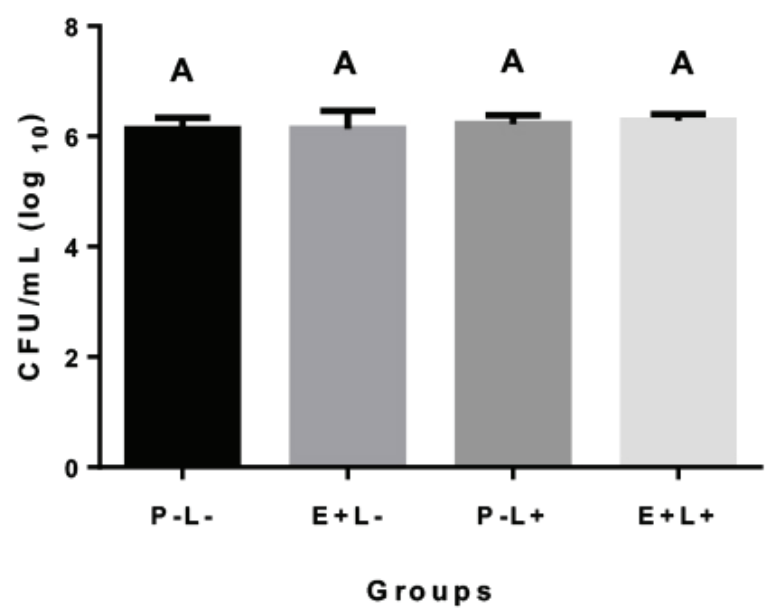

Figure 3 - Mean and standard deviation of the number of CFU/ $\mathrm{mL}\left(\log _{10}\right)$ obtained from PDI of planktonic cultures of S. mutans mediated by erythrosine $10 \mu \mathrm{M}$ and blue LED, $p=0.3644$. Different letters indicate statistical differences among groups.
$E+$ blue LED

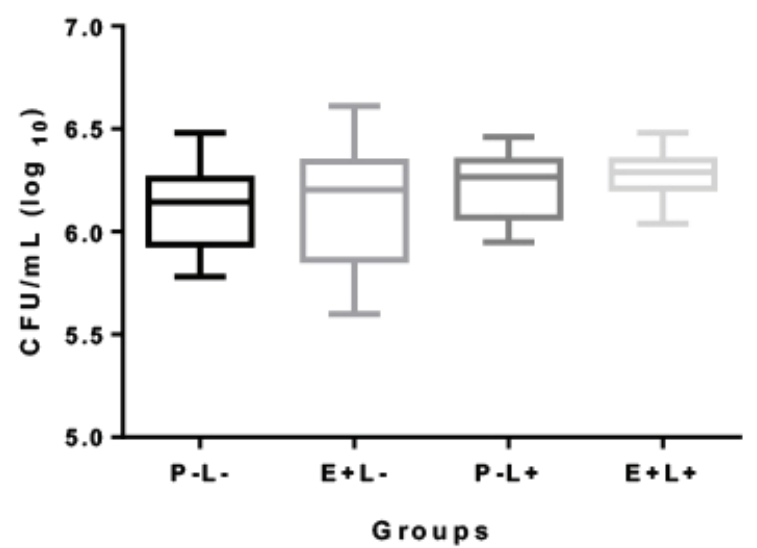

Figure 4 - Median values (crossbar), interquartile range (IQR box), minimum and maximum values of $\mathrm{CFU} / \mathrm{mL}\left(\log _{10}\right)$ obtained from PDI of planktonic cultures of $S$. mutans mediated by erythrosine $10 \mu \mathrm{M}$ and blue LED.

Table II - Descriptive statistical analysis of data from the CFU/ $\mathrm{mL}$ of $S$. mutans treated with physiologic solution alone (P$\mathrm{L}-)$, erythrosine $(E+L-)$, physiologic solution and LED $(P-L+)$, erythrosine and LED $(E+L+)$

\begin{tabular}{|c|cccc|}
\hline Values & P-L- & EUL- & P-LU & EULU \\
\hline Minimun & 5.78 & 5.60 & 5.95 & 6.04 \\
\hline First Q & 5.98 & 6.01 & 6.10 & 6.24 \\
\hline Median & 6.15 & 6.21 & 6,27 & 6.29 \\
\hline Third Q & 6.23 & 6.32 & 6.34 & 6.32 \\
\hline Maximum & 6.48 & 6.61 & 6.46 & 6.48 \\
\hline Mean & 6.13 & 6.14 & 6.22 & 6.28 \\
\hline
\end{tabular}

\section{DISCUSSION}

Photodynamic inactivation (PDI) is an alternative technique that uses a specific photosensitizer and light source to control microorganisms, including oral pathogens $[12,20]$. It is an interesting method to prevent the bacterial resistance of antibiotic drugs and chemical agents that is minimally invasive and nontoxic. There are some advantages of PDI when comparing to conventional antimicrobial agents, such as killing of the target microorganisms is quick (related to the parameters used), the lack of resistance by the specific organisms, and the antimicrobial effects can be localized to a specific site, preventing disruption of normal microflora in other regions [14,21-23]. 
Currently, PDI has been widely investigated as an adjunct therapy to control the growth of $S$. mutans, and consequently, the development of dental caries. Several previous studies demonstrated that PDI is capable of reducing biofilms formed by $S$. mutans, becoming a very useful strategy for dental biofilm control $[13,18,24]$. In addition, PDI can be used as a supplementary approach for killing remaining isolated cells of $S$. mutans in the contaminated dentine prior to a definitive restoration [25]. In this context, this study investigated the antibacterial photodynamic effect of erythrosine that is a common dye used as a photosensitizer for PDI.

The in vitro investigation using a planktonic model is a major step for guiding protocols/parameters for more future detailed studies, when considering illumination aspects (related to the light sources) and concentration (related to the dyes) [26]. The in vitro planktonic essays are also essential to determine the efficacy of potential antimicrobial agents. Most methods for evaluating antimicrobial activity of new antimicrobial candidates are based on determining cell viability in microbial suspensions [27]. According to the American Society of Microbiology, a CFU-reduction of $3 \log _{10}$ is necessary to use the term "antimicrobial" [25].

In this study, the light source used was a blue LED that presents many advantages: it is usually found in the dental office for lightcuring composite resin materials and tooth whitening and it does not damage the oral tissues. Moreover, it is inexpensive, has a broad spectrum output, and is easy to operate $[14,15]$. Dentists could use their usual LEDs to perform PDI in their offices, thereby reducing the need to acquire a laser or different types of LEDs. Some studies have showed that the use of LEDs alone exerts little or no antimicrobial effect $[28,29]$. Erythrosine has been used in dental practice for the detection of dental biofilms at concentrations of 9-25 $\mu \mathrm{M}$ [30]. The current study showed no effect with erythrosine in planktonic culture of $S$. mutans. Then, the null hypothesis was rejected for erythrosine.

At the moment, there are many photosensitizers based on porphyrin, phenothiazinium, phthalocyanine, and chlorin derivatives. However, the future of PDI is highly dependent on the development of more efficient photosensitizers [31]. In addition to the photochemical yield, there are several factors that are important for PDI efficiency, such as tissue/cell localization and membrane binding [29]. Therefore, having a large photochemical yield is certainly a necessary characteristic required for developing new photosensitizers [32].

Esper et al. [33] showed photodynamic inactivation of planktonic cultures and Streptococcus mutans biofilms for prevention of white spot lesions during orthodontic treatment using hematoporphyrin IX and modified hematoporphyrin IX. The study showed an interesting result with hematoporphyrin IX and modified hematoporphyrin IX, killing 54\% and 100\% (p $<0.0001$ ) of $S$. mutans in planktonic culture, respectively. In addition, no reduction of $S$. mutans biofilms was observed with the use of hematoporphyrin IX on both types of brackets. However, modified hematoporphyrin IX showed a significant inactivation of $S$. mutans biofilms, with $44 \%$ and 53\% survival rate (P = 0.0020 and $P=0.0004$ ), respectively, seen on metallic and ceramic brackets. This is the first study using hematoporphyrin IX and modified hematoporphyrin IX as photosensitizers on planktonic culture and biofilms of $S$. mutans. In the present study was used the same wavelength (Figure 2), the same energy and strain of $S$. mutans (UA 159).

Costa et al. [19] tested the effect of PDI using rose bengal and erythrosine with a LED over planktonic cultures of $S$. mutans (ATCC 35688) and Pereira et al. [13] over a biofilm of S. mutans (ATCC 35688) and S. sanguinis (ATCC 10556). The first authors concluded that PDI with both photosensitizers exerted an antimicrobial effect, 
with a reduction of 6.86 (rose bengal) and 5.16 $\log _{10}$ (erythrosine) on the strain studied. The last study showed a reduction of 0.62 (rose bengal) and $0.52 \log _{10}$ (erythrosine) for $S$. mutans biofilms and 0.95 (rose bengal) and $0.88 \log _{10}$ (erythrosine) for $S$. sanguinis biofilms. Both studies used a wavelength range of $440-460 \mathrm{~nm}$, similar to this study. The concentrations of the photosensitizer were 2 and $5 \mu \mathrm{M}$, respectively, and the concentration used in this experiment was $10 \mu \mathrm{M}$. However, in the present study, no effect was observed with erythrosine, despite of the use of a similar wavelength (Figure 2). The same energy was used in both studies but a different strain of $S$. mutans was used (UA 159).

Metcalf et al. [34] used a light dose fractionation (500-550 nm) and erythrosine $(22 \mu \mathrm{M})$ over $S$. mutans biofilms (NCTC 10449). Those authors observed a reduction of $2 \log _{10}$ after 5 min of continuous light irradiation and a reduction of $3.7 \log _{10}$ when using fractionation of the light dose. They highlighted the clinical potential of this photosensitizer because, with the light dose fractionation, irradiation time could be reduced to clinically acceptable levels. In the current study, a reduction of $6.78 \log _{10}$ was observed for the HP+L+ group when compared to the control (P-L-) and the irradiation time of 60 seconds was clinically acceptable. However, PDI with erythrosine did not induce a reduction in the numbers of $\mathrm{CFU} / \mathrm{mL}$ when compared to the control group (P-L-).

Another in vitro study [12], evaluated the effect of PDI on $S$. mutans biofilm (ATCC 25175), using a halogen light-curing unit $(400-520 \mathrm{~nm})$ and erythrosine $(20 \mu \mathrm{M})$. The results showed a significant decrease in $S$. mutans biofilm formation and a potential for preventing dental caries. They used a higher concentration of erythrosine and a light source with a higher emission spectrum when compared with this work.

Habiboallah et al. [35] investigated the periodontal bactericidal effect on $P$. gingivalis and $F$. nucleatum using erythrosine and an LED (440-480 nm) compared with a diode laser $(800 \mathrm{~nm})$. Those authors concluded that erythrosine at $22 \mu \mathrm{M}$ in the presence of a blue light and infrared diode laser could be considered as a potential approach of PDI against Gram-negative periodontal pathogenic species. Nagata et al. [36], in a review of PDI for dental caries, reported that erythrosine is the most hydrophilic photosensitizer and the Gram-positive bacteria allow better penetration of this dye, but Habiboallah et al. [35] and Silva et al. [37] showed good results with Gram-negative bacteria.

Ishiyama et al. [38] used an Nd-YAG laser and three different photosensitizers: rose bengal, erythrosine, and phloxine at $10 \mu \mathrm{M}$ to compare their ability to produce singlet oxygen in relation to their bactericidal activity on Streptococcus mutans (JCM 5705). Rose bengal showed the highest bactericidal activity against $S$. mutans, followed by erythrosine and phloxine. One of the main reasons for the discrepancy between the singlet oxygen generating ability and bactericidal activity was the incorporation efficiency of the photosensitizers into the bacterial cells. They used the same concentration of the dye as in our study, but also used an NdYAG laser (532 nm).

Fracalossi et al. [39] evaluated singlet oxygen quantum yield of erythrosine solutions illuminated with a halogen light source $(375-525 \mathrm{~nm})$ in comparison to a LED array $(480-560 \mathrm{~nm})$, and the photodynamic effect of erythrosine dye in association with the halogen light source on S. mutans (UA 159). They concluded that photodynamic response of erythrosine induced by the halogen light was capable of killing $S$. mutans. It is within the range used in the present study with the same strain.

There are two basic mechanisms related to the lethal damage caused to bacteria by PDI. The first is related to the DNA damage and the second to the damage caused to the cytoplasmic membrane, allowing leakage of cellular contents or inactivation of membrane transport systems and enzymes. Breaks in both single and double stranded DNA and 
the disappearance of the plasmid supercoiled fraction have been detected in both grampositive and gram-negative bacteria. Another potential causes of cell death include the alteration of cytoplasmic membrane proteins, the disturbance of cell wall synthesis, and the appearance of a multi lamellar structure near the septum of dividing cells; loss of potassium ions from the cells may also be a possible method of bacterial death [40].

In this study, no significant difference in the number of $\mathrm{CFU} / \mathrm{mL}$ was observed between the control group (P-L-) and the groups treated in the dark with the photosensitizers only $(\mathrm{HP}+\mathrm{L}-$ and $\mathrm{E}+\mathrm{L}-)$ or the group irradiated in the absence of the dye (P-L+). These findings agree with the basic principles of PDI, in which application of the dye or the light source alone has no antibacterial effect [41].

No reduction in $S$. mutans was observed in the groups submitted to PDI $(\mathrm{E}+\mathrm{L}+)$ when compared to the others. Erythrosine absorb light in the 400-550 $\mathrm{nm}$ ranges, and the light source used in the present study emits light in the 420-480 range. The association between erythrosine and light do not resulted in cellular death.

Since it was observed that erythrosine had no antimicrobial activity against $S$. mutans cells, the next steps will be to test other concentrations of erythrosine photosensitizer and/or to using a modified erythrosine in planktonic cultures and on biofilms of $S$. mutans formed in vitro, on dental surfaces, and on oral biofilms developed in vivo, in animal models.

The synthesis of new and more efficient photosensitizers is an interesting approach to improve results in PDI and for clinical research in the future.

\section{CONCLUSION}

The results showed that Streptococcus mutans cells were not sensitive to PDI using erythrosine and a blue LED, in the parameters used.

\section{REFERENCES}

1. Loesche WJ. Role of Streptococcus mutans in human dental decay, Microbiological reviews 1986;50(4):353-80.

2. Hamilton IR, Buckley ND. Adaptation by Streptococcus mutans to acid tolerance, Oral microbiology and immunology 1991;6(2):65-71.

3. Bowden GHW. Which bacteria are cariogenic in humans? In:Dental Caries: Markers of High and Low Risk Groups and Individuals. Cambridge University Press, Cambridge, 1991.

4. Sansone C, Van Houte J, Joshipura K, KentR, Margolis HC. The association of mutans streptococci and non-mutans streptococci capable of acidogenesis at a low $\mathrm{pH}$ with dental caries on enamel and root surfaces. J Dent Res. 1993;72(2):508-16

5. Svensater G, Welin J, Wilkins JC, Beighton D, Hamilton IR. Protein expression by planktonic and biofilm cells of Streptococcus mutans. FEMS Microbiol Lett. 2001Nov 27;205(1):139-46.

6. O'Toole GA, Kolter R. Initiation of biofilm formation in Pseudomonas fluorescens WCS365 proceeds via multiple, convergent signalling pathways: a genetic analysis. Mol Microbiol. 1998 May;28(3):449-61.

7. Soukos NS, Goodson JM. Photodynamic therapy in the control of oral biofilms. Periodontol 2000.2011Feb;55(1):143-66

8. Bowden GH, Hamilton IR. Survival of oral bacteria. Crit Rev Oral Biol Med. 1998:9(1):54-85

9. Featherstone JD. The science and practice of caries prevention. J Am Dent Assoc 2000;131(7):887-99.

10. Featherstone JD. The continuum of dental caries-evidence for a dynamic disease process. J Dent Res. 2004;83 Spec No C:C39-42.

11. Caufield PW, Griffen AL. Dental caries. An infectious and transmissible disease. Pediatr Clin North Am. 2000 0ct;47(5) 1001-19.

12. Lee YH, Park HW, Lee JH, Seo HW, Lee SY. The photodynamic therapy on Streptococcus mutans biofilms using erythrosine and dental halogen curing unit. Int J Oral Sci 2012;4(4):196-201.

13. Pereira CA, Costa AC, Carreira CM, Junqueira JC, Jorge AO. Photodynamic inactivation of Streptococcus mutans and Streptococcus sanguinis biofilms in vitro. Lasers Med Sci 2013;28(3):859-64

14. Konopka K, Goslinski T.Photodynamic therapy in dentistry.J Jent Res 2007;86(8):694-707.

15. Meisel P,Kocher T.Photodynamic therapy for periodontal diseases: state of the art. JPhotochem Photobiol B2005;79(2):159-70.

16. Allaker RP,Douglas CW. Novel antimicrobial therapies for dental plaquerelated diseases. Int J Antimicrob Agents 2009;33(1):8-13.

17. Wood S, Metcalf D, Devine D, Robinson C. Erythrosine is a potential photosensitizer for the photodynamic therapy of oral plaque biofilms. J Antimicrob Chemother 2006;57(4):680-4.

18. Costa AC, de Campos Rasteiro VM, Pereira CA, da Silva Hashimoto ES, Beltrame,MJr., Junqueira JC, Jorge AO. Susceptibility of Candida albicans and Candida dubliniensis to erythrosine-and LED-mediated photodynamic therapy, Arch Oral Biol. 2011 Nov;56(11):1299-305.

19. Costa AC, Chibebe Junior J, Pereira CA, Machado AK, Beltrame Junior M, Junqueira JC, etal. Susceptibility of planktonic cultures of Streptococcus mutans to photodynamic therapy with a light-emitting diode. Braz Oral Res 2010;24(4):413-8.

20. Wilson M. Lethal photosensitisation of oral bacteria and its potentia application in the photodynamic therapy of oral infections. Photochem Photobiol Sci 2004;3(5):412-8. 
21. Trindade FZ, Pavarina AC, Ribeiro AP, Bagnato VS, Vergani CE, Costa CA. Toxicity of photodynamic therapy with LED associatedto Photogem: an in vivo study. Lasers Med Sci 2012;27(2):403-11.

22. Wainwright M, Crossley KB. Methylene blue - a therapeutic dye for all seasons? JChemother 2002;14(5):431-43.

23. Tavares A, Carvalho CM, Faustino MA, Neves MG, Tome JP,Tome AC, etal. Antimicrobial photodynamic therapy: study of bacterial recovery viability and potential development of resistance after treatment. Mar Drugs 2010;8(1):91105.

24. de Freitas MT, Soares TT, Aragao MG, Lima RA, Duarte S, Zanin IC. Effect of Photodynamic Antimicrobial Chemotherapy on Mono and Multi-Species Cariogenic Biofilms: A Literature Review. Photomed Laser Surg. 2017 May;35(5):239-45

25. Cieplik F,Buchalla W, Hellwig E, Al-Ahmad A, Hiller KA, Maisch T, Karygianni L. Antimicrobial photodynamic therapy as an adjunct for treatment of deep carious lesions-a systematic review. Photodiagnosis Photodyn Ther.2017 Jun;18:54-62

26. Paschoal MA, Tonon CC, Spolidorio DM, Bagnato VS, Giusti JS, Santos-Pinto L.Photodynamic potential of curcumin and blue LED against Streptococcus mutans in a planktonic culture. Photodiagnosis Photodyn Ther 2013;10(3):3139.

27. Balouiri M, Sadiki M, Ibnsouda SK. Methods for in vitro evaluating antimicrobial activity: a review.JPharm Anal 2016;6(2):71-9.

28. Zanin IC, Goncalves RB, Junior AB, Hope CK, Pratten J. Susceptibility of Streptococcus mutans biofilms to photodynamic therapy: an in vitro study. $J$ Antimicrob Chemother 2005(2);56:324-30.

29. Engelmann FM, Mayer I, Gabrielli DS, Toma HE, Kowaltowski AJ, Araki K, et al. Interaction of cationic meso-porphyrins with liposomes, mitochondria and erythrocytes. J Bioenerg Biomembr 2007;39(2):175-85.

30. Marsh PD, Bevis RA, Newman HN, Hallsworth AS, Robinson C, Weatherell JA. Antibacterial activity of some plaque-disclosing agents and dyes.Caries Res1989;23(5):348-50.

31. Savellano MD, Hasan T. Targeting cells that overexpress the epidermal growth factor receptor with polyethylene glycolated BPD verteporfin photosensitizer immunoconjugates. Photochem Photobiol. 2003 Apr;77(4):431-9.
32 Castano AP,Demidova TN, Hamblin MR. Mechanisms in photodynamic therapy: part two-cellular signaling, cell metabolism and modes of cell death, Photodiagnosis Photodyn Ther.2005 Mar;2(1):1-23.

33. Esper MÂLR, Junqueira JC, Uchoa AF,Bresciani E, Rastelli ANS, Navarro RS, Gonçalves SEP.Photodynamic inactivation of planktonic cultures and Streptococcus mutans biofilms for prevention of white spot lesions during orthodontic treatment: An in vitro investigation. Am J of Orthodontics and Dentofacial Orthopedics 2019;155(2):243-53.

34. Metcalf D, Robinson C, Devine D, Wood S. Enhancement of erythrosinemediated photodynamic therapy of Streptococcus mutans biofilms by light fractionation. J Antimicrob Chemother 2006;58(1):190-2

35. Habiboallah G, MahdiZ, Mahbobeh NN, Mina ZJ, Sina F,Majid Z. Bactericidal effect of visible light in the presence of erythrosine on Porphyromonas gingivalis and Fusobacterium nucleatum compared with diode laser, an in vitro study. Laser Ther 2014;23(4):263-71.

36. Nagata JY,Hioka N, KimuraE, Batistela VR, Terada RS, Graciano AX, et al. Antibacterial photodynamic therapy for dental caries: evaluation of the photosensitizers used and light source properties. Photodiagnosis Photodyn Ther 2012;9(2):122-31.

37. Silva JR, Cardoso G, Maciel RR, de Souza NC. Morphological alterations on Citrobacter freundii bacteria induced by erythrosine dye and laser light. Lasers Med Sci 2015;30(1):469-73.

38. Ishiyama K, Nakamura K, Ikai H, Kanno T, Kohno M, Sasaki K, et al. Bactericidal action of photogenerated singlet oxygen from photosensitizers used in plaque disclosing agents. PLoS One 2012;7(5):e37871.

39. Fracalossi C, J.Y.Nagata JY,D.S. Pellosi DS, R.S. Terada RS, N. Hioka N,M.L Baesso ML, Sato F, Rosalen PL, Caetano W, Fujimaki M. Singlet oxygen production by combining erythrosine and halogen light for photodynamic inactivation of Streptococcus mutans. Photodiagnosis Photodyn Ther. 2016 Sep;15:127-32.

40. Sudhakara Reddy R, Ramya K, Tatapudi R, Gudapati S, Sai Madhavai N Sai Kiran C. Photo dynamic therapy in oral diseases. Int JBiol Med Res 2012;3(2):1875-83.

41. Plaetzer K, Krammer B, Berlanda J,BerrF,Kiesslich T.Photophysics and photochemistry of photodynamic therapy: fundamental aspects. Lasers Med Sci.2009Mar:24(2):259-68

\section{Maria Ângela Lacerda Rangel Esper \\ (Corresponding address)}

Department of Restorative Dentistry, Institute of Science and Technology, São

Paulo State University-UNESP

Avenida Engenheiro Francisco José Longo, 777, Jardim São Dimas, São José dos

Campos, SP, ZIP code: 12245-000, Brazil

Date submitted: 2019 Aug 28

E-mail: angela_esper@hotmail.com 